Gulawentah: Jurnal Studi Sosial

ISSN 2528-6293 (Print); ISSN 2528-6871 (Online)

Vol. 5, No. 2, Desember 2020, Hal 77-86

Tersedia Online: http://e-journal.unipma.ac.id/index.php/gulawentah

\title{
Perubahan Sosial Ekonomi pada Industri Keramba Jaring Apung di Curug Apu Jatiluhur selama Pandemi Covid-19
}

\author{
Silvy Mei Pradita* dan Humar Sidik \\ Pendidikan Sejarah, FKIP UHAMKA, Kampus B: Jl. Tanah Merdeka Kp Rambutan, \\ Pasar Rebo, Jakarta Timur, Indonesia \\ Email: *praditasilvy@yahoo.co.id; humarsidik4@gmail.com
}

Naskah diterima: 23/5/2020; Revisi: 31/5/2020; Disetujui: 26/10/2020

\begin{abstract}
Abstrak
Penelitian ini bertujuan untuk mengulas secara mendalam dampak yang disebabkan oleh pandemi Covid-19 kepada industri Keramba Jaring Apung (KJA) serta strategi apa yang diterapkan industri ini dalam menghadapi pandemi Covid-19. Metode yang diterapkan dalam penelitian ini adalah kualitatif dengan pendekatan fenomenologi model Miles dan Huberman, karena dianggap relevan dalam mendeskripsikan secara naratif hasil penelitian yang telah dilakukan. Teknik dan prosedur pengambilan data dilakukan dengan cara observasi, wawancara dan studi dokumentasi. Oleh karena itu, peneliti berperan dalam hal perencana, pengumpul data, penganalisis dan penulis hasil dari penelitian ini. Teknik analisis data terdiri dari reduksi data, penyajian data, dan penarikan kesimpulan atau verifikasi. Hasil penelitian ini menunjukkan bahwa Curug Apu yang terletak di Kabupaten Purwakarta yang berada di wilayah perairan waduk Jatiluhur, memiliki manfaat bagi masyarakat sekitar, yaitu digunakan sebagai lokasi usaha perikanan air tawar atau biasa disebut dengan Keramba Jaring Apung (KJA). Di Kabupaten Purwakarta, usaha KJA ini menjadi salah satu sektor yang berkontribusi besar dalam meningkatkan kesejahteraan dan membuka peluang kerja untuk masyarakat. Di masa sekarang pandemic covid-19, terdapat ancaman lain yang mengganggu pelaksanaan industri ini. Dengan penyebarannya yang luar biasa cepat serta sulit dideteksi siapa saja pengidapnya, membuat industri ini juga turut terkena dampaknya. Apalagi setelah diproklamirkannya sistem physical distancing yang bertujuan untuk menjaga jarak serta diterapkannya PSBB di beberapa wilayah. Secara tidak langsung kebijakan tersebut mempengaruhi pangsa pasar industri KJA. Salah satu cara yang digunakan yaitu dengan menyimpan dan menahan penjualan ikan patin dan nila di pasaran hingga harga yang ada dipasaran tersebut kembali stabil.
\end{abstract}

Kata kunci: Covid-19; Keramba Jaring Apung; Perubahan Ekonomi

\section{Sosio-Economic Change in the Floating Net Cage Industry in Curug Apu Jatiluhur during the Covid-19 Pandemic}

\begin{abstract}
This study aims to examine in depth the impact caused by the Covid-19 pandemic to the floating net cages industry and the strategies implemented by the industry in dealing with the Covid-19 pandemic. The method applied in this research is qualitative with the phenomenological approach of Miles and Huberman's model, because it is considered relevant in describing narratively the results of the research that has been done. Data collection techniques and procedures are carried out by observation, interview and documentation study. Therefore, researchers play a role in terms of planners, data collectors, analyzers and authors of the
\end{abstract}

DOI: 10.25273 /gulawentah.v5i2.6611

Some rights reserved. 
results of this study. Data analysis techniques consist of data reduction, data presentation, and drawing conclusions or verification. The results of this study indicate that Curug Apu located in Purwakarta Regency which is in the Jatiluhur reservoir waters, has benefits for the surrounding community, which is used as a location for freshwater fisheries business or commonly referred to as Floating Net Cages (KJA). In Purwakarta Regency, this KJA business has become one of the sectors that has greatly contributed to improving welfare and opening up employment opportunities for the community. In the current co-19 pandemic, there are other threats that interfere with the implementation of this industry. With its spread is extremely fast and difficult to detect whoever is infected, making this industry also affected. Especially after the proclamation of the physical distancing system which aims to keep a distance and the implementation of PSBB in some areas. The policy indirectly affects the market share of the KJA industry. One method used is to save and hold the sale of catfish and tilapia in the market until prices in the market are stable.

Keywords: Economic Change; Covid-19; Floating Net Cages;

\section{Pendahuluan}

Novel Coronavirus Desease 2019 atau lebih dikenal Covid-19 merupakan sebuah virus yang menyerang saluran pernapasan dan mampu menyebabkan hal yang fatal hingga berujung kematian. Virus ini sering disamakan dengan SARS-CoV, padahal nyatanya dalam tes genetik yang dilakukan oleh WHO pada bulan Januari lalu kedua virus ini memiliki perbedaan. Walaupun sama-sama berjenis virus Corona. Akan tetapi secara garis besar dapat disepakati bahwasanya virus ini mampu menular dengan begitu cepatnya dikarenakan seorang individu yang terinfeksi virus ini mampu menampung triliunan partikel virus yang siap bereplikasi sehingga memberikan peluang menyebar yang jauh lebih besar dalam tubuh seorang manusia (Heymann \& Nahoko Shindo, 2020). Kemudian ketika individu yang terinfeksi tersebut bersin atau mengeluarkan cairan dari mulut ataupun hidung yang didalamnya terkandung virus maka ia akan mampu menginfeksi orang yang terkena cairan yang dikeluarkan sang inang virus. Untuk mengatasi ancaman ini maka pemerintah memberlakukan kebijakan kepada setiap masyarakat untuk menjaga jarak dan menggunakan masker demi meminimalisir penyebaran Covid-19.

Sehubung dengan penyebaran virus yang kian membesar, pemerintah mulai melarang adanya sistem sosial yang melibatkan banyak orang dalam sebuah tempat. Faktor inilah yang kemudian memaksa sekelompok masyarakat untuk mengurangi aktifitasnya diluar rumah dan lebih memilih bekerja di dalam rumah. Akibatnya sistem ekonomi dan sosial masyarakat mengalami perubahan secara signifikan dalam tempo waktu yang begitu cepat. Sistem perdagangan yang umumnya dilakukan secara langsung dengan tawar menawar yang menjadi ciri khasnya terpaksa dialihkan kedalam sistem transaksi online. Alhasil hanya sebagain pedagang saja yang mampu melakukannya dan sisanya terpaksa harus menutup usahanya atau memaksa tetap buka dengan keuntungan yang kecil serta resiko tertular virus yang besar.

Bukan hanya sebatas pedagang kecil saja, kebijakan tersebut juga berpengaruh pada bidang industri. Dikarenakan bidang ini berfungsi memasok makanan ataupun barang bagi masyarakat. Namun beberapa industri juga mengalami lonjakan signifikan dalam hal permintaan barang akibat pandemi ini, sebut saja masker ataupun handsanitizer. Walaupun begitu sebagian industri dipaksa untuk tutup sementara oleh pemerintah. Maka dari itu hal ini terbilang kontras, karena ada industri yang terkena dampak positif dan disisi lain terdapat industri yang terkena dampak negatif. Faktor tersebut yang kemudian menimbulkan pertanyaan, bagaimana dengan eksistensi industri-industri lainnya, salah satunya yaitu "keramba jaring apung". Keramba jaring apung sendiri merupakan sebuah tempat budidaya perikanan yang diletakan dalam badan air yang dalam dan luas seperti waduk, danau ataupun laut. Sehingga industri ini secara tidak langsung sangat menguntungkan karena mampu memproduksi begitu banyak ikan dengan tingkat resiko kegagalannya yang rendah (Gunarto, 2003). Atas dasar tersebut maka eksistensi keramba jaring apung dipertanyakan ditengah pandemi Covid-19, 
karena sifatnya yang berguna sebagai pemasok makanan bagi masyarakat. Apakah mengalami kerugian karena kesulitan dalam memasarkan hasil panennya ataukah justru sebaliknya mendapatkan keuntungan yang signifikan karena kebutuhan masyarakat yang meningkat, namun dengan syarat melakukan strategi tertentu agar tidak tertelan dampak pandemi Covid-19.

Mengacu berbagai macam permasalahan tersebut maka penelitian ini hadir untuk mengulas lebih dalam terkait dengan eksistensi keramba jaring apung ditinjau dalam perpektif sosial ekonomi. Dimulai dengan pengertian dan pangsa pasar keramba jaring apung kemudian dilanjutkan dengan dampak yang dialami oleh industri ini selama pandemi Covid-19, lalu ditutup dengan strategi yang diterapkan oleh industri keramba jaring apung demi mengatasi ancaman dari wabah Covid-19. Dengan adanya penelitian ini maka diharapkan dapat memperkaya literatur terkait dengan perubahan sosial dan ekonomi pada industri keramba jaring apung, dikarenakan artikel dan buku yang membahas keramba jaring apung begitu sedikit. Hanya sebatas website dan blog saja yang menyajikan tentang keramba jaring apung dan itupun tidak secara mendalam. Apalagi jika topik ini dihubungkan dengan pandemi Covid-19 sekarang, maka dapat dikatakan masih belum ada yang mengkajinya. Maka dari itu dengan adanya penelitian ini diharapkan mampu memberikan sumbangsih pada keragaman ilmu pengetahuan yang ada.

Soekanto (2012) memaparkan bahwa perubahan sosial adalah perubahan-perubahan pada lembaga kemasyarakatan di suatu masyarakat yang mempengaruhi sistem sosialnya, termasuk nila-nilai, sikap, dan pola perilaku di antara kelompok di masyarakat. Adapun Lauer (dalam Ranjabar, 2015) mengatakan bahwa perubahan sosial sebagai suatu proses inklusif yang merujuk kepada perubahan sosial berbagai tingkat kehidupan manusia dan mulai dari individual hingga global. Perubahan sosial tidak terjadi begitu saja, beberapa faktor internal yang menyebabkan suatu perubahan itu terjadi, di antaranya bertambah dan berkurangnya suatu penduduk, adanya penemuan baru, timbulnya pertentangan/konflik, dan terjadinya revolusi atau pemberontakan (Martono, 2012). Sedangkan faktor eksternal yaitu terjadinya bencana alam atau yang mempengaruhi kondisi lingkungan fisik, timbulnya peperangan, dan adanya pengaruh dari kebudayaan masyarakat lain. Terdapat dampak yang ditimbulkan dari adanya suatu perubahan sosial, yang terbagi menjadi dampak positif dan negatif. Dampak postitif meliputi munculnya penemuan baru yang dapat membantu aktivtas manusia, munculnya nilai dan norma baru yang lebih relevan, dan munculnya lembaga atau institusi baru. Sedangkan dampak negatif yaitu perubahan yang terlalu cepat dapat menimbulkan anomie yaitu keadaan di mana nilai yang lama sudah tidak relevan dan nilai baru belum terbentuk, akibatnya manusia kehilangan pegangan moral, yang dapat memicu kemunduran moral. Perubahan sering juga memunculkan konflik sosial yang dapat menimbulkan disintegrasi dan perpecahan.

Terdapat beragam bentuk perubahan sosial yang terjadi di masyarakat (Wrahatnala, 2009): (1) Perubahan secara lambat (evolusi) ialah sebuah perubahan yang memerlukan waktu lama dan merupakan rentetan perubahan kecil yang saling mengikuti dengan lambat. Pada evolusi ini, perubahan terjadi dengan sendirinya tanpa adanya rencana atau kehendak tertentu; (2) Perubahan secara cepat (revolusi) adalah suatu perubahan yang dapat mengubah sendi-sendi pokok kehidupan masyarakat seperti sistem kekeluargaan, politik, ekonomi, dan hubungan antar manusia. Dalam revolusi, perubahan yang terjadi ada yang direncanakan terlebih dahulu, namun ada juga yang tidak direncanakan. Selain itu ada yang dijalankan dengan kekerasan atau tanpa kekerasan. Dalam perubahan secara cepat, kemungkinan timbulnya tindakan kekerasan dan sifat anarki sangat besar terjadi; (3) Perubahan kecil adalah perubahan yang terjadi pada unsur-unsur struktur sosial yang tidak membawa pengaruh langsung atau berarti bagi masyarakat; (4) Perubahan besar ialah suatu perubahan yang berpengaruh terhadap masyarakat dan lembagalembaganya. Sebagai contoh adalah adanya industrialisasi yang telah mengubah masyarakat agraris menjadi masyarakat industri. Perubahan itu memberikan pengaruh dalam kehidupan masyarakat seperti terlihat dalam hubungan antar sesama. Pada masyarakat agraris hubungan antarsesama terlihat akrab dan menunjukkan adanya kebersamaan. Namun pada masyarakat 
industri hal tersebut mengalami perubahan, yang mana hubungan lebih didasarkan pada pertimbangan untung rugi; (5) Perubahan yang dikehendaki merupakan perubahan yang diperkirakan atau direncanakan terlebih dulu oleh pihak yang hendak mengadakan perubahan (agent of change) (6) Perubahan yang tidak dikehendaki ialah perubahan yang terjadi di luar jangkauan pengawasan masyarakat dan dapat menyebabkan dan dapat mengakibatkan timbulnya hal-hal yang tidak diharapkan oleh masyarakat (7) Perubahan struktural adalah perubahan yang sifatnya mendasar dan menyebabkan timbulnya reorganisasi dalam masyarakat (8) Perubahan proses adalah perubahan yang sifatnya tidak mendasar dan merupakan penyempurnaan dari perubahan yang terjadi sebelumnya.

\section{Metode Penelitian}

Metode memiliki relasi yang erat kaitannya dengan sebuah proses, langkah, teknik yang sistematis dalam menggali suatu informasi pada disiplin ilmu tertentu demi mendapatkan bahan-bahan yang akan diteliti (Sjamsuddin, 2016). Berangkat dari pernyataan tersebut, maka dalam penelitian ini metode yang digunakan adalah kualitatif dengan pendekatan fenomenologi model Miles dan Huberman. Penggunaan metode ini sengaja dipilih karena dianggap relevan dalam mendeskripsikan secara naratif hasil penelitian yang telah dilakukan. Maka dari itu secara tidak langsung dalam penggunaan data dan sumber data, peneliti menggunakan data primer dan sekunder. Data primer didapatkan oleh peneliti dari seorang informan yang memahami atau terjun langsung dalam permasalahan yang dikaji dalam penelitian ini. Kemudian untuk sumber sekunder, peneliti menggunkaan studi literatur yang dianggap relevan demi mendukung penelitian ini, sehingga dalam penelitian ini teknik dan prosedur pengambilan data dilakukan dengan cara observasi, wawancara dan studi dokumentasi.

Observasi, merupakan pengamatan dan pencatatan berbagai hal yang didapatkan selama proses penelitian berlangsung. Lalu wawancara sendiri merupakan cara yang digunakan untuk memperoleh data dengan cara bertanya kepada seseorang yang memahami atau bahkan bagian dari permasalahan yang diangkat peneliti baik secara langsung atau dengan cara menggunakan perangkat teknologi yang dianggap relevan untuk mendapatkan informasi tersebut. Kemudian studi dokumentasi merupakan sebuah cara untuk mendapatkan data dengan cara mencari informasi dari berbagai sumber yang terkait dengan penelitian yang diambil seperti buku, jurnal, artikel, majalah, arsip dan sumber dokumen lainnya yang relevan demi menunjang penelitian dan melengkapi hasil yang diperoleh dari observasi dan wawancara.

relevan oleh peneliti dalam menggali informasi lebih dalam demi mendukung tema penelitian Maka dalam hal ini peneliti berperan dalam hal perencana, pengumpul data, penganalisis dan penulis hasil dari penelitian ini. Penelitian ini sendiri dilaksanakan di daerah Curug Apu, Jatiluhur dikarenakan dianggap yang diangkat.

Teknik analisis data yang digunakan oleh peneliti dalamm hal ini adalah teknik analisis data model Miles dan Huberman yang terdiri dari reduksi data, penyajian data, dan penarikan kesimpulan atau verifikasi. Demi menguji keabsahan data yang didapatkan maka dalam hal ini peneliti menggunakan teknik triangulasi penelitian dan ketekunan dalam pengamatan. Triangulasi senndiri merupakan sebuah teknik yang digunakan dengan cara membandingkan hasil dari data yang diperoleh di lapangan dengan data yang lain yang masih berkaitan dengan sumber, metode atau teori (Bungin, 2015). Sedangkan ketekunan pengamat dalam hal ini berarti peneliti dituntut untuk fokus dan membatasi berbagai pengaruh dengan mencoba menemukan ciri-ciri dan unsur-unsur dalam situasi yang relevan agar menghasilkan kedalaman data. 


\section{Hasil dan Pembahasan Hasil Penelitian}

Curug Apu merupakan sebuah kampung di Desa Panyindangan Kecamatan Sukatani Kabupaten Purwakarta. Kampung Curug Apu ini berada di wilayah perairan waduk Jatiluhur. Oleh karena itu, di lokasi ini terdapat banyak Keramba Jaring Apung (KJA) dan merupakan salah satu tempat yang selalu diburu oleh para pemancing di alam liar. Ikan yang menjadi buruan para pemancing ini adalah ikan nila, di samping tentunya ikan-ikan jenis lainnya. Dari hasil wawancara yang dilakukan pada Bapak Baban yang merupakan salah satu pemilik Keramba Jaring Apung di Kampung Curug Apu memaparkan bahwa salah satu manfaat dari adanya waduk Jatiluhur bagi masyarakat sekitar digunakan sebagai lokasi usaha perikanan air tawar atau biasa disebut dengan Keramba Jaring Apung (KJA). Di Kabupaten Purwakarta, usaha KJA ini menjadi salah satu sektor yang berkontribusi besar dalam meningkatkan kesejahteraan dan membuka peluang kerja untuk masyarakat. Salah satunya adalah Rumah Tangga Perikanan (RTP) yang terdiri dari nelayan (penangkapan), pembudidaya ikan, pengolah (pedagang), dan buruh perikanan. Budidaya ikan dengan sistem KJA di waduk Jatiluhur terbagi atas 5 zona yang tersebar di seluruh wilayah perairan waduk Jatiluhur dengan jumlah dengan jumlah maksimal keramba setiap pemilik usaha sebanyak 20 petak. Namun masih ditemukan beberapa pembudidaya yang memiliki jumlah keramba lebih dari 20 petak. Khusus untuk jumlah Kolam Jaring Apung di Kampung Curug Apu berjumlah sekitar 2000 lebih.

Menurut Bapak Baban, dengan mendirikan KJA, tidak srta merta akan langsung memanen keuntungan yang berlipat serta menjadikan seorang individu menjadi kaya. Karena ada begitu banyak faktor yang perlu diperhatikan serta permasalahan yang dihadapi. Di masa sekarang, terdapat ancaman lain yang mengganggu pelaksanaan industri ini, yaitu pandemi Covid-19. Dengan penyebarannya yang luar biasa cepat serta sulit dideteksi siapa saja pengidapnya, membuat industri ini juga turut terkena dampaknya. Apalagi setelah diproklamirkannya sistem physical distancing yang bertujuan untuk menjaga jarak serta diterapkannya PSBB di beberapa wilayah. Secara tidak langsung kebijakan tersebut mempengaruhi pangsa pasar industri KJA. Walaupun tidak dapat dinafikan apabila KJA merupakan industri bahan makanan mentah yang pasti selalu dibutuhkan oleh masyarakat demi memenuhi kebutuhan hidupnya. Akan tetapi tetap saja dampak yang dirasakan ada, karena jumlah permintaan pasar menurun dan hal tersebut berpengaruh kepada harga pemasaran ikan yang ada (Baban, 2019).

Maka dari itu dengan adanya pandemi Covid-19 penghasilan yang didapatkan menjadi menurun ketimbang hari biasanya.Untuk mengatasi permasalahan tersebut, mau tidak mau para pekerja dan pemilik usaha industri KJA harus memutar otak agar tidak terjadinya deficit. Salah satu cara yang digunakan yaitu dengan menyimpan dan menahan penjualan ikan patin dan nila di pasaran hingga harga yang ada dipasaran tersebut kembali stabil. Karena kedua jenis ikan ini tidak terlalu sulit diurus serta mampu bertahan hidup tanpa diberikan pakan dalam kurun waktu yang lama. Namun apabila terdapat kebutuhan mendesak, jenis ikan ini juga terpaksa harus dijual. Sedangkan untuk jenis ikan lainnya yang biasa dibudidayakan seperti ikan mas, jika sudah waktunya harus dijual. Rentang waktu ikan mas yang harus dipanen berkisar 3 bulan. Karena jika jenis ikan ini tetap dipertahankan dan disimpan terlebih dahulu seperti ikan patina tau nila, maka akan merugikan para pemilik, sebab ikan ini harus terus diberikan pakan, jika tidak akan mati. Selain itu jika sistem pemberian pakannya 
juga terlibat dengan mita agen yang menjual pakan, maka akan semakin merugikan pemilik usaha jika tidak segera dipanen (Baban, 2019).

\section{Pembahasan}

1. Keramba Jaring Apung sebagai Mata Pencaharian Masyarakat

Indonesia merupakan negara maritim dengan kepulauan terbanyak di dunia, dengan dominasi wilayah lautnya kurang lebih 5,4 juta $\mathrm{km}^{2}$ (Pangemanan et al., 2014). Atas dasar tersebut, banyak penduduk Indonesia yang menjadikan laut, danau, sungai dan perairan lainnya sebagai tempat untuk memenuhi kebutuhan hidupnya. Sama halnya seperti masyarakat yang tinggal di sekitar bendungan Jatiluhur yang merupakan bendungan terbesar di Indonesia yang membendung aliran sungai Citarum di Kecamatan Jatiluhur Kabupaten Purwakarta Provinsi Jawa Barat. Bendungan Jatiluhur membentuk waduk dengan genangan seluas kurang lebih $( \pm) 83 \mathrm{~km}^{2}$ dan keliling waduk kurang lebih ( \pm$) 150 \mathrm{~km}^{2}$. Bendungan Jatiluhur merupakan bendungan multiguna, yaitu: (a) sebagai pembangkit listrik dengan kapasitas terpasang 197,5 MW; (b) sebagai pengendali banjir di Kabupaten Karawang dan Bekasi; (c) sebagai sumber pengairan irigasi untuk lahan seluas 242.000 ha; (d) sebagai pemasok air untuk kebutuhan rumah tangga dan industri; (e) sebagai pemasok air untuk kegiatan budidaya perikanan air; (f) sebagai lokasi wisata (Fitri, Hidayat, \& Gandhi, 2016).

Sebagai salah satu titik sentral mata pencaharian masyarakat Indonesia, perairan memberikan penghasilan yang begitu besar tidak hanya bagi negara melainkan juga bagi masyarakat yang bekerja di sana. Selain itu sektor dalam bidang perairan seperti perikanan memberikan layanan kepada para masyarakat berupa sumber protein hewani yang tinggi. Dengan berbagai aspek menguntungkan tersebut ditambah dukungan oleh alam Indonesia yang mempunyai keragaman fisiografis membuat sektor perikanan menjadi primadona dalam hal pemenuh kebutuhan sehari-hari, mengalahkan sektor pariwisata dan lainnya. Dengan temperatur air yang tinggi dan stabil di wilayah tropis sepanjang tahun, memungkinkan penangkapan ikan yang tiada henti (Japsamsah et al., 2014). Akan tetapi itu hanya berlaku di laut lepas selain itu risiko yang dihadapi dalam hal ini berupa iklim alam secara langsung. Maka dari itu cara alternatif yang dapat dilakukan yaitu dengan melakukan budidaya.

Budidaya dianggap sebagai cara yang tepat untuk memaksimalkan potensi perikanan yang ada di Indonesia. Dikarenakan seiring perkembangannya sektor ini terus meraup keuntungan yang berlipat ganda dari tahun ke tahun. Salah satu bentuk budidaya yang ada sekarang ini yaitu Industri Keramba Jaring Apung. Keramba Jaring Apung atau yang biasa disingkat KJA merupakan sebuah sistem budidaya perikanan yang memanfaatkan badan air dalam seperti waduk, danau atau laut. Maka dari itu KJA dalam prakteknya menerapkan sistem budidaya intensif dengan prinsip utama semua ikan baik tawar maupun laut dapat dipelihara dalam keramba. Untuk memaksimalkan usaha pemeliharaan ini maka budidaya KJA harus mempertimbangkan berbagai hal, diantaranya yaitu:

Pertama, lingkungan hidup seputar lahan dan habitat. Dalam hal ini kedalaman yang dimiliki KJA menjadi penentu jenis ikan apa yang dapat ditangkarkan. Karena kedalaman perairan menunjukan jenis organisme yang mendiaminya, penetrasi cahaya dan juga penyebaran plankton sehingga dengan memperhitungkan kedalaman akan meminimalisir terjadinya kegagalan dalam budidaya ikan. Umumnya untuk budidaya jenis ikan laut seperti kerapu dan lainnya, kedalaman yang dianjurkan sekitar 5-25 m. Selain kedalam air juga turut memberikan pengaruh yang cukup signifikan pada 
budidaya ikan dengan jenis KJA, misalnya ph yang terkandung di dalam air, suhu air yang berubah ketika terjadinya perubahan iklim dan lainnya. Hal-hal seperti itu turut diperhatikan demi mendapatkan hasil yang optimal dalam budidaya ikan di dalam keramba (Rosyidah \& Zamroni, 2019).

Kedua, pakan yang berkelanjutan, yaitu jenis pakan yang akan dipilih seperti apa, pakan alami ataukah buatan. Selain itu dalam penggunaannya sebisa mungkin pakan yang digunakan tidak berganti-ganti. Dalam kasus industri, harga menjadi salah satu hal vital yang perlu diperhitungkan demi mendapatkan hasil yang maksimal dengan biaya yang relatif minimal sehingga mencegah terjadinya inflasi pendapatan. Ketiga, penyakit yang menyerang ikan. Bukan hanya di alam bebas saja, dalam penangkaran ikan juga dapat terkena penyakit. Maka dari itu penting untuk melakukan pencegahan dan penanggulangan demi mengatasi penyakit yang mengancam budidaya ikan di KJA. Salah satu cara yang dapat dilakukan yaitu dengan memilih benih yang sehat sebelum melakukan penyebaran serta menyiapkan antibiotik yang sering menjangkiti jenis ikan yang sedang ditangkarkan (Kordi, 2001).

Sebetulnya budaya ikan dengan sistem KJA adalah salah satu kegiatan ekonomi yang berpotensi menurunkan kualitas perairan waduk, karena kandungan dari pakan ikan, kotoran ikan, dan sampah buangan dari aktivitas KJA adalah limbah bagi waduk Jatilihur apabila tidak dikelola dengan baik (Purnomo, 2013).

\section{Perubahan Sosial Ekonomi Akibat Pandemi Covid-19}

Perubahan sosial suatu konsep yang sangat luas cakupannya dan sering terjadi di masyarakat. Namun, perlu diketahui juga bahwa istilah perubahan sosial bersifat taksa atau ambigu. Seperti yang dikatakan oleh Peter Burke dalam bukunya Sejarah dan Teori Sosial edisi kedua, yaitu:

"Perlu ditekankan dari awal bahwa istilah "perubahan sosial" bersifat taksa. Istilah ini kadang-kadang digunakan dalam arti sempit, mengacu kepada perubahan dalam struktur sosial (keseimbangan antarkelas sosial, misalnya), tetapi juga tak jarang dipakai dalam arti yang jauh lebih luas, mencakup organisasi politik, ekonomi, dan budaya (Burke, 2015)."

Dari pernyataan Burke tersebut dapat diketahui bahwa perubahan sosial mencakup dari area yang kecil atau sempit sampai ke area yang luas dan besar. Tetapi, perubahan sosial yang tercatat atau bisa dikatakan sebagai sejarah adalah perubahan sosial yang mencakup area yang luas dan besar. Dalam perspektif sosiologi perubahan sosial didefinisikan sebagai transformasi dalam organisasi masyarakat, dalam pola berpikir dan dalam perilaku pada waktu tertentu.

Menurut Farley, perubahan sosial adalah perubahan pola perilaku, hubungan sosial, lembaga dan struktur sosial pada waktu tertentu. Sedangkan menurut Hawley, perubahan sosial adalah setiap perubahan yang tak terulang dari sistem sosial sebagai suatu kesatuan (Sztompka, 2011).

Kemudian perubahan ekonomi adalah perubahan dalam sistem transaksi ekonomi yang berkaitan dengan produksi, distribusi dan konsumsi. Mengacu pada definisi tersebut, maka dapat ditarik kesimpulan bahwasanya perubahan sosial ekonomi merupakan sebuah sistem perubahan yang muncul akibat adanya hubungan sosial sehingga secara tidak langsung berdampak terhadap eksistensi perekonomian baik individu maupun negara dalam jangka waktu tertentu. Dalam hal ini penyebab utama terjadinya perubahan sosial dan ekonomi adalah pandemi Covid-19. Virus yang 
menyerang saluran pernapasan ini, membuat setiap individu mau tidak mau harus melakukan kebijakan physical distancing, yaitu sebuah prosedur jaga jarak yang diproklamirkan oleh WHO. Di Indonesia sendiri demi memberlakukan kebijakan "jaga jarak" maka diterapkanlah PSBB (Pembatasan Sosial Berskala Besar), demi meminimalisir angka pasien yang terjangkit virus Covid-19.

Namun bukan hanya sebatas prosedur jaga jarak saja yang ditetapkan oleh pemerintah, melainkan juga aturan yang melarang individu untuk berkumpul dalam jumlah besar ditempat tertentu. Alhasil sistem ekonomi yang melibatkan interaksi dalam jumlah besar seperti pasar menjadi terganggu dalam hal penghasilan. Tidak hanya sebatas itu efek domino dari diterapkannya kebijakan ini, turut berdampak pada sektor industri dan perusahaan-perusahaan baik swasta maupun negeri serta buruh dan yang lainnya. Bahkan jika terus dibiarkan berlanjut terus menerus seperti ini yang menjadi sasaran selanjutnya adalah perekonomian negera.

Maka dari itu pandemi Covid-19 benar-benar merusak tatanan sosial dan ekonomi masyarakat yang ada, tidak jarang karena dampak yang disebabkannya membuat begitu banyak individu yang terkena PHK, pemotongan gaji karyawan atau bahkan bangkrutnya sebuah perusahaan. Walaupun begitu disatu sisi masih terdapat juga beberapa industri yang mendapatkan keuntungan misalnya industri masker, jual beli online dan sebagainya. Namun secara garis besar dampak negatif yang diberikan oleh pandemi Covid-19 dalam sosial ekonomi jauh lebih besar.

\section{Dampak Pandemi Covid-19 terhadap Industri Keramba Jaring Apung dan Strategi} Menghadapinya

Potensi lahan perikanan di Indonesia yang begitu luas ditambah dengan dukungan kondisi alam yang telah memumpuni membuat industri perikanan lebih menjanjikan ketimbang industri lainnya. Salah satu industri perikanan yang terkenal saat ini dengan omset yang menjanjian adalah industri keramba jaring apung. Dalam prakteknya industri KJA menempatkan banyak ikan di dalam sebuah tempat dengan perhitungan tertentu yang telah mapan, sehingga dalam satu kali panen industri ini akan meraup keuntungan yang menjanjikan.

Daerah Curug Apu Jatiluhur, Purwakarta Jawa Barat merupakan salah satu tempat yang menerapkan industri KJA dalam hal budidaya ikan. KJA yang terletak di dalam waduk Jatiluhur ini secara historis dimaksudkan sebagai kompensasi bagi penduduk yang wilayahnya terkena genangan air, tetapi mereka tetap bertahan disana, baik sebagai petani atau hanya bertempat tinggal disana. Seiring berjalannya waktu kegiatan inipun menjelma menjadi salah satu industri yang menguntungkan. Untuk skala usahanya sendiri, industri ini tidak semuanya merupakan industri besar dengan modal yang banyak. Masih banyak para petani dengan modal-modal kecil yang turut mengembangkan budidaya ikan menggunakan sistem KJA. Walaupun begitu tetap saja baik industri besar atau kecil, keuntungan yang didapatkan dari budidaya ikan ini cukup untuk memenuhi kebutuhan sehari-hari dan meningkatkan taraf hidup masyarakat disana (Nastiti et al., 2001).

Dunia saat ini sedang diserang oleh pandemi Covid-19, sebuah virus yang menyerang bagian pernapasana manusia tanpa pandang usia, agama, rasa tau apapun. Indonesia termasuk salah satu dari mayoritas negara yang terkena serangan Covid-19. Untuk mencegah penyebaran virus yang semakin cepat dan meminimalisir jumlah pasien Covid-19, pemerintah memberlakukan kebijakan physical distancing yang memaksa masyarakat menjaga jarak dan membatasi kontak secara langsung dalam batas 
waktu tertentu. Efek yang diberikan dari diterapkannya kebijakan ini begitu signifikan dalam mempengaruhi kehidupan ekonomi seorang individu maupun keluarga.

Berbagai kegiatan transaksi ekonomi yang melibatkan pertemuan masyarakat dalam jumlah besar dibatasi, kegiatan-kegiatan lainnya yang mengundang kerumunan orang juga dibatasi. Alhasil hampir semua masyarakat dan mata pencahariannya mengalami penurunan, walau ada beberapa industri yang mengalami kenaikan dalam jumlah permintaan secara signifikan seperti masker dan handsanitizer tapi dibalik itu semua pekerjaan-pekerjaan dan industri-industri lainnya mengalami dampak yang merugikan. Salah satu industri yang terkena dampak tersebut adalah industri keramba jaring apung di Curug Apu Jatiluhur.

\section{Simpulan}

Industri dalam sektor perikanan yang selalu dianggap memiliki prospek menjanjikan ikut terkena dampak negatif dari serangan pandemi Covid-19. Pendapatan yang didapatkan dari hasil industri ini turun dari pada hari biasanya, walau tidak terlalu signifikan juga. Namun perlu diketahui bahwasanya penurunan yang tidak terlalu signifikan tersebut karena sudah diatasi dengan berbagai macam strategi oleh para pekerja dan pemilik usaha keramba jaring apung ini. Misalnya dengan memasarkan hasil panen berupa ikan mas sesuai waktu panennya. Dikarenakan ikan jenis ini terlalu bergantung dengan pakan, jika tidak segera dijual ketika sudah waktunya maka akan memakan biaya jauh lebih besar untuk pakan yang diberikan. Sedangkan ikan jenis lain seperti nila dan patin yang memiliki kemampuan bertahan hidup lebih tinggi, disimpan terlebih dahulu hingga harga penjualan ikan patin dan nila menjadi stabil. Karena dengan kemampuan bertahan hidup yang kuat, ikan jenis ini tidak akan terlalu bermasalah apabila tidak diberi pakan dalam tempo waktu tertentu, hanya saja jika memanen ikan tanpa melewati batas waktu panen akan berpengaruh pada kualitas daging dan juga ukuran ikan tersebut. Namun tetap saja apabila muncul keadaan yang mendesak atau permasalahan lainnya yang tidak terduga, maka ikan ini juga terpaksa harus dijual. Maka dari itu setelah melakukan penelitian ini akan menarik apabila melihat perubahan selanjutnya yaitu, setelah pandemi Covid-19 usai dan kehidupan mulai berjalan normal.

\section{Daftar Pustaka}

Baban. (2019). Wawancara Pemilik KJA.

Bungin, B. (2015). Analisis Data Penelitian Kualitatif (ke-9). Raja Grafindo Persada.

Burke, P. (2015). Sejarah dan Teori Sosial (Kedua). Yayasan Pustaka Obor Indonesia.

Gunarto, A. (2003). Pengembangan Sea Farming Budidaya Keramba Jaring Apung (KJA) Kerapu (Ephinelphelus Sp.) di Indonesia. Jurnal Matematika, Saint, Dan Teknologi, 4(1), $35-44$.

Heymann, D. L., \& Nahoko Shindo. (2020). Covid-19: what is next for public health? The Lancet, $\quad 395(10224), \quad$ 542-545. $\quad$ https://doi.org/https://doi.org/10.1016/S01406736(20)30374-3

Japsamsah, C. I., Dien, C. R., \& Andaki, J. A. (2014). Analisis Sensitivitas Usaha Budidaya Ikan Nila (Oreochromis Niloticus) di Desa Tatelu Kecamatan Dimembe Kabupaten 
Minahasa Utara. Akulturasi, 2(4), 175-180.

Kordi, M. G. (2001). Usaha Pembesaran Ikan Kerapu di Tambak. Kanisius.

Nastiti, A. S., Krismono, K., \& Kartamihardja, E. S. (2001). Dampak Budi Daya Ikan Dalam Keramba Jaring Apung Terhadap Peningk,Atan Unsur N Dan P Di Perairan Waduk Saguling, Girata, Dan Jatiluhur. Jurnal Penelitian Perikanan Indonesia, 7(2), 22. https://doi.org/10.15578/jppi.7.2.2001.22-30

Pangemanan, O. V. L., Mantjoro, E., \& Jusuf, N. (2014). Dampak Kebijakan Moratorium terhadap Industri Perikanan (Studi Kasus Kota Bitung). Akulturasi, 2(4), 181-191.

Rosyidah, L., \& Zamroni, A. (2019). Persepsi Masyarakat Terhadap Usaha Budi Daya Karamba Jaring Apung (KJA) Ikan Kerapu Di Kabupaten Buleleng, Provinsi Bali. Marina, 5(1), 29-37.

Sjamsuddin, H. (2016). Metodologi Sejarah (M. Nursam (Ed.); Cetakan 3). Ombak.

Sztompka, P. (2011). Sosiologi Perubahan Sosial (T. W. B.S. (Ed.); Keenam). Prenada Media Group. 